\title{
Construction and validation of a plasmid for HIV-1 phenotyping assays using Luminescence
}

\author{
Construção e Validação de um plasmídeo para ensaios de fenotipagem do HIV-1 através \\ de Luminescência
}

\begin{abstract}
Construcción y validación de un plásmido para ensayos de fenotipado del HIV-1 usando luminiscencia
\end{abstract}

Bianca Cristina Duarte Vivarini ${ }^{1}$, Aislan de Carvalho Vivarini ${ }^{2 *}$.

\begin{abstract}
Objective: The objective of these studies was the construction of a recombination vector for HIV-1 Integrase containing luciferase reporter gene, for the generation of recombinant viruses that can be used in phenotyping assays with integrase inhibitors. Methods: In this work, the vector pNL4-3Luc was molecularly manipulated in order to delete the integrase gene and build a vector for recombination of integrases from different virus subtypes. Results: As a result, viruses with recombinant integrases were generated in HEK293T cells transfected with plasmids, showing significant levels of luminescence. After the purification of the produced viral particles, susceptible lymphocytes were infected with the viruses containing the recombinant integrases and luminescence was detected in both integrases from HIV-1 subtype B and subtype C. Conclusion: The observation of light emission from cells infected by viruses with different integrases can be an efficient method to assess the susceptibility of these viruses in the presence of specific inhibitors for HIV-1 Integrase.
\end{abstract}

Key words: HIV-1, AIDS, Antiretroviral therapy.

\section{RESUMO}

Objetivo: O objetivo desses estudos foi a construção de um vetor de recombinação para a Integrase do HIV-1 contendo o gene repórter da luciferase, visando a geração de vírus recombinantes que possam ser utilizados em ensaios de fenotipagem com inibidores da integrase. Métodos: Neste trabalho, o vetor pNL43Luc foi manipulado molecularmente para deletar o gene da integrase e construir um vetor para recombinação de integrases de diferentes subtipos de vírus. Resultados: Como resultados, os vírus com as integrases recombinantes foram gerados nas células HEK293T transfectadas com os plasmídeos, apresentando níveis significativos de luminescência. Após a purificação das partículas virais produzidas, linfócitos suscetíveis foram infectados com os vírus contendo as integrases recombinantes e houve a detecção de luminescência tanto nas integrases oriundas do HIV-1 subtipo B quanto do subtipo C. Conclusão: A observação da emissão de luz de células infectadas por vírus com diferentes integrases pode ser um método eficiente para avaliar a suscetibilidade desses vírus na presença de inibidores específicos para a integrase do HIV-1.

Palavras-chave: HIV-1, AIDS, Terapia antiretroviral.

\footnotetext{
${ }^{1}$ Faculdade de Medicina, Universidade Federal do Rio de Janeiro, Rio de Janeiro - RJ.

2 Instituto de Biofísica Carlos Chagas Filho, Universidade Federal do Rio de Janeiro, Rio de Janeiro - RJ.

*E-mail: aislanvivarini@biof.ufrj.br
}

SUBMETIDO EM: 4/2021

ACEITO EM: 4/2021

PUBLICADO EM: 4/2021 


\section{RESUMEN}

Objetivo: El objetivo de estos estudios fue la construcción de un vector de recombinación para la integrasa del HIV-1 que contenga el gen indicador de la luciferasa, con el objetivo de generar virus recombinantes que puedan utilizarse en ensayos de fenotipado con inhibidores de la integrase. Métodos: En este trabajo, el vector pNL4-3Luc fue manipulado molecularmente para eliminar el gen de la integrase y construir un vector para la recombinación de integrases de diferentes subtipos de virus. Resultados: Como resultado, se generaron virus con integrasas recombinantes en células HEK293T transfectadas con plásmidos, mostrando niveles significativos de luminiscencia. Después de la purificación de las partículas virales producidas, los linfocitos susceptibles se infectaron con los virus que contenían las integrasas recombinantes y se detectó luminiscencia en ambas integrasas del subtipo B y subtipo C del HIV-1. Conclusión: Observar la emisión de luz de las células infectadas por virus con diferentes integrase puede ser un método eficaz para evaluar la susceptibilidad de estos virus en presencia de inhibidores específicos de la integrase del HIV-1.

Palabras clave: HIV-1, AIDS, Terapia antirretroviral.

\section{INTRODUCTION}

Acquired Immunodeficiency Syndrome (AIDS) was first reported in 1981 by the Center for Disease Control (CDC, 2001). The etiologic agent of this disease is the Human Immunodeficiency Virus (HIV), whose infection mainly affects the immune system leading to lymphadenopathies and the incidence of opportunistic diseases (GALISTEU KJ, et al., 2015).

HIV is classified as one of the genus Lentivirus, due to its ability to cause chronic and latent infections (GERMAN ADVISORY COMMITTEE BLOOD, 2016). Epidemiological data from UNAIDS (United Nations Program on HIV/AIDS) points to about 34 million people infected worldwide (UNAIDS, 2018).

Phylogenetically, HIV is divided into two types, HIV-1 and HIV-2, originated from different zoonotic infections. Based on phylogenetic studies, HIV-1 is divided into 4 groups: $M$ (main); The (outlier); N (non-M and non-O) and more recently in P (PLANTIER J, et al., 2009; PEETERS M, et al., 2014). Group M includes more than $95 \%$ of the viruses isolated worldwide. It consists of at least nine subtypes (A to D, F to $\mathrm{H}, \mathrm{J}$ and $\mathrm{K})$ and 50 Recombinant Forms (Circulating Recombinant Forms - CRF and Unique Recombinant Forms URF) (HEMELAAR J, et al., 2011).

Most of the studies on HIV-1 have been carried out in the United States and countries in Europe, where subtype $B$ is the most prevalent. Despite growing, studies on non-B subtypes are scarce, especially with regard to antiviral therapy, vaccine studies and resistance (NEUBERT J, et al, 2016).

HIV is a retrovirus with a complex genomic structure, consisting of two identical RNA strands with positive polarity, with an approximate size of $9.5 \mathrm{~Kb}$ each. It has 9 genes that code for 15 proteins, of which, Gag, Pol and Env are polyproteins that are subsequently cleaved into individual proteins, common to all retroviruses. The three proteins generated from the GagPol precursor polyprotein are: PR (protease), TR (reverse transcriptase) and IN (integrase), which are individualized during viral sprouting by the action of the protease (SKITTRALL JP, et al., 2019).

HIV-1 infects cells of the host's immune system, mainly lymphocytes, macrophages and dendritic cells since they have CD4, CXCR4 and/or CCR5 molecules on their surface, making them susceptible to the virus (CUNNINGHAM AL, et al., 2010; BRACQ L, et al., 2018). Despite the innumerable efforts of the scientific community in the search for the improvement of antiretroviral treatment, the infection by the virus leads to the Acquired Immunodeficiency Syndrome, a disease without cure. HIV infection is clinically characterized by the acute and chronic phases. During these periods, the level of circulating viral particles remains low and the population of TCD4+ cells decrease progressively. If the levels of TCD4+ become lower than $350 \mathrm{cells} / \mathrm{mm}^{3}$ in the blood, with a simultaneous increase in viral load, the individual enters the stage of AIDS. At this stage, 
the individual is susceptible to several opportunistic infections that are capable of leading to death more quickly (ALBARILLO F and O'KEEFE P, 2016).

Antiretroviral therapy represents a potent intervention for the prevention of HIV transmission. In Brazil, according to data from the preliminary version of the recommendations for antiretroviral therapy for adults living with HIV/AIDS, the recommendation for starting treatment is based on the TCD4+ lymphocyte count (MINISTRY OF HEALTH, 2019).

The therapy is mainly based on the inhibition of viral enzymes fundamental to the replicative cycle of HIV1 , such as RT, PR and IN, in addition to fusion inhibitors and co-receptor antagonists. The current treatment consists of administering a cocktail, known as Highly Active Antiretroviral Therapy (HAART), which is the combination of RT inhibitors and PR inhibitors (LU DY, et al., 2018). Integrase inhibitors (INIs) comprise the class of inhibitors most recently used in rescue therapy. Despite the great benefits attributed to this therapy, with regard to the reduction of viral levels in treated patients, the observation of therapeutic failure has represented an obstacle to treatment against AIDS (BLANCO JL and MARTINEZ-PICADO J, 2012; HARDY I, et al., 2015). Thus, rescue therapy for these patients becomes increasingly fundamental. Currently, the main class of rescue antiretrovirals used is integrase inhibitors (INI).

The first representative of the class of INIs approved for treatment by the FDA in 2007 is Raltegravir (OARAC, 2012). This has a good therapeutic potency in patients infected with multiresistant viruses. Given the above, Integrase Inhibitors are a promising class of antiretroviral drugs, since in the host cell there are no proteins homologous to IN, and few adverse effects are expected (KOLAKOWSKA A, et al., 2019). Despite the clinical benefits, recent studies demonstrate the appearance of therapeutic failure associated with the resistance mutations to Raltegravir (SANTOS JR, et al., 2015; PUJARI SN, et al., 2018).

Studies to analyze therapeutic failure at INI have become important in view of the urgency of clinical evaluation of resistance and cross-resistance. Many research groups, as well as companies, have developed genotypic and phenotypic tests for studies of HIV Integrase activity (HEGER E, et al., 2016; SALADINE F, et al., 2018). In view of the above, the development of new phenotypic and genotypic IN tests, as well as trials for the discovery of new drugs is necessary. The clinical relevance for accurate diagnoses in patient's resistant to INI makes the choice for the best treatment clinically more effective.

Therefore, the work aims to build and validate a plasmid recombination vector for HIV-1 Integrase containing the luciferase reporter gene, aiming at the production of recombinant viruses, and the test can be used in phenotyping assays with integrase inhibitors drugs.

\section{METHODS}

\section{Plasmids}

The plasmids used were pNL4-3Luc (CONNOR NR, et al., 1995), and pNL4-3AInt, previously developed in the molecular virology laboratory of the Institute of Biology at the Federal University of Rio de Janeiro. These plasmids are derived from pNL4-3 which has the complete HIV-1 subtype B genome. Plasmid preparations were performed using the QIAGEN Plasmid Purification kit to obtain the vectors in bacteria Escherichia coli XL-1Blue cultured in $5 \mathrm{~mL}$ of liquid LB medium with $100 \mu \mathrm{g} / \mathrm{mL}$ ampicillin, as indicated in the kit manual (QIAGEN® Plasmid Purification Handbook).

\section{Polymerase Chain Reaction (PCR)}

The cloning verification was performed by PCR using specific primers for the amplification of luciferase: Nef-Ext F-5-'GTACAGGCAGAAAGCAGCTGCTTATATG-3' and Nef-Ext R5'AGAGAGACCCAGTACAGGCAGAAA 3 ', as well as for amplification of integrase gene: Int $F$ 5'CAAGCACAACCAGATAARAGTGA 3' and Int R-5'TGGGATGTGTACTTCTGAACTTA-3'. The amplification was analyzed after electrophoresis in $0.8 \%$ agarose gel and, to visualize the DNA, ethidium bromide with excitation by ultraviolet light was used. 


\section{Nucleotide sequencing}

To confirm the genotypes of the recombined Integrases, sequencing of the amplicons was carried out. The PCR products were purified using the PCR Centrifugal Filter Devices kit (Millipore, Massachusetts USA), according to the protocol described by the manufacturer. The sequencing reaction was using the Big Dye ${ }^{\circledR}$ terminator v3.1 cycle sequencing kit (Applied Biosystem, California - USA), according to the manufacturer's protocol. The sequences obtained were deposited in the database of Stanford University, CA - USA, "HIVseq Program: Sequence Analysis", whose access is free via the internet (http://hivdb.stanford.edu/index.html).

\section{Homologous recombination in vitro}

A homologous in vitro recombination protocol was performed based on studies developed by (GIBSON DG, et al., 2009). For this, the vector pNL4-3Luc $\Delta$ Int digested with BsTE-II and amplicons Integrase control was used, originating from the vector pNL4-3Luc and subtype B or C. The reaction of recombination was incubated at $50^{\circ} \mathrm{C}$ for 60 minutes and then $5 \mu \mathrm{L}$ were used for transformation into chemocompetent XL1-blue bacteria. The confirmation of positive colonies was performed by PCR for the Integrase region, followed by nucleotide sequencing.

\section{Plasmid transfection in HEK 293-T cells and Luminescence Detection}

In a $25 \mathrm{~cm}^{2}$ culture bottle, $1 \times 10^{6} \mathrm{HEK} 293-\mathrm{T}$ cells were transfected using FuGene $\AA$, as indicated in the kit manual (Promega, Wisconsin - USA). After 48 hours, the culture supernatants from the transfection were collected and stored at $-80^{\circ} \mathrm{C}$. HEK 293-T cells grown in a $25 \mathrm{~cm}^{2}$ bottle were washed with $5 \mathrm{~mL}$ of $1 \mathrm{X}$ PBS and $1 \mathrm{~mL}$ of $0.25 \%$ trypsin-EDTA was used to dissociate adherent cells and centrifuged at $1200 \mathrm{rpm}$ for 8 minutes. The supernatant was discarded and the cell pellet was lysed with $200 \mu \mathrm{L}$ of lysis buffer (Promega, Wisconsin - USA). The lysate was left at $-80^{\circ} \mathrm{C}$ for 20 minutes, centrifuged again and the collected supernatant was transferred to a 96-well reading plate. The luminescence reading was performed on the GloMax® Microplate Luminometer by the Promega company, according to the manufacturer's protocol (Promega, Wisconsin-USA).

\section{Test for infection of HIV-susceptible MT-4 cells}

The supernatant of HEK 293-T cells collected after 48 hours of transfection, in which $300 \mu \mathrm{L}$ of the supernatant was added to $300 \mu \mathrm{L}$ of MT-4 cells (human T-type lymphocytic cells) at $1 \times 10^{6}$ density for for $2 \mathrm{~h}$ at room temperature. The supernatant was removed and $3 \mathrm{~mL}$ of RPMI complete medium was used to resuspend the infected MT-4 cells. In a 96-well round bottom plate, $200 \mu \mathrm{L}$ of the resuspended medium was added to 12 wells, for each supernatant under test. After $72 \mathrm{~h}$, cells in culture were collected to perform the Luminescence assay.

\section{RESULTS}

\section{Construction and obtainment of the integrase recombination vector pNL4-3Luc $\Delta$ Int}

In order to construct a recombinant vector for HIV-1 Integrases, the vector pNL4-3Luc was chosen because it contains the luciferase reporter gene in the place of the HIV-1 nef gene. The strategy used to build the recombinant region was to remove the region of the Integrase gene (867 bp) from the vector and in its place to build a unique restriction site for the enzyme BsTEll. The vector pNL4-3 $\Delta$ Int was also used in which the unique site for BsTEII was introduced in place of the Integrase gene by means of site-directed mutagenesis. Thus, to facilitate cloning, we used the strategy of deleting the region of the Integrase gene from the vector pNL4-3Luc (4279 bp) with the use of the restriction enzymes Sal-I and Spe-I, the same ones used to cut the $\Delta$ Int region of the vector pNL4-3AInt and thus, connect it to the vector pNL4-3Luc deleted in the same region, resulting in the vector that we would call pNL4-3Luc $\Delta$ Int (Figure 1). 
Figure 1 - Illustrative representation of the cloning strategy used to generate the recombinant vector of integrases with the reporter luciferase gene.

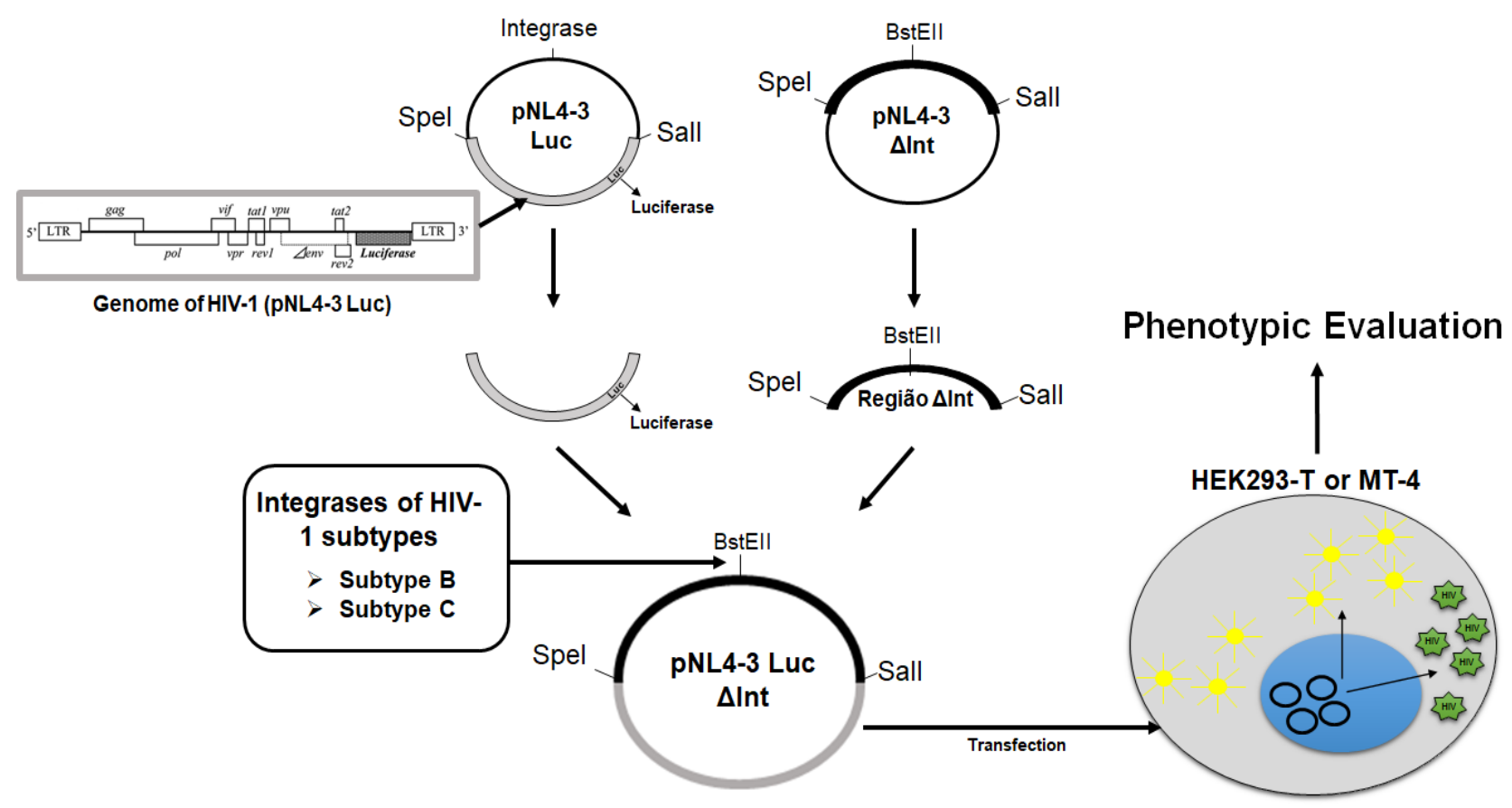

Note: The plasmid at the top left represents the vector pNL4-3Luc, the vector on the right represents pNL4$3 \Delta$ Int. Upon being digested by the restriction enzymes Sal-I and Spe-I, the aim was to purify the larger fragments for pNL4-3Luc (in which it contains the luciferase gene and the HIV-1 genome) deleted the region which contains the integrase gene - represented by the gray box) and the smallest fragment for pNL4-3tInt (in which it does not contain the integrase gene and in its place, there is a restriction site for BsTEII). After digestion, the binding of the fragments would result in the recombinant vector of integrases with the reporter luciferase gene: pNL4-3LucAInt. Image built on Microsoft Power-Point software. Source: Vivarini BCD e Vivarini AC, 2021.

Through the analysis of the nucleotide sequence of both vectors, it was decided to use the enzymes Sal-I and Spe-I to perform the cloning. In the vector pNL4-3Luc the restrictions flank the region that contains the integrase gene, which promotes the deletion of this gene in this vector; in the pNL4-3AInt vector, these enzymes digest the region that flanks the previously deleted integrase site, this region corresponding to the unique site for BsTE-II. In view of this analysis, the digestion of the vectors with these enzymes was carried out. As a result, both vectors digested, with the fragments resulting from pNL4-3Luc digestion being larger than pNL4-3LInt. The difference between the smallest fragment of the pNL4-3Luc (4279 pb) and the

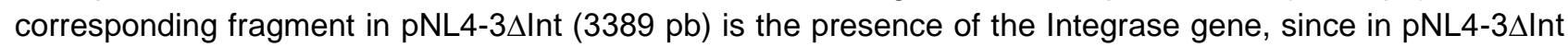
this gene was deleted and, in its place, the unique site for BsTE-II was created.

In the case of the vector pNL4-3Luc, the objective was to obtain the largest fragment, corresponding to the complete nucleotide region of the vector without the deleted $4279 \mathrm{bp}$ containing the Integrase gene. As for the vector pNL4-3AInt, the fragment was the smallest (3389 bp), corresponding to the region previously deleted from the integrase gene and as a substitute it consists of the restriction site region for BsTE-II. Both fragments were extracted from the gel and the ligation reaction was carried out, as described in the material and methods. The cloning strategy is illustrated in Figure 1.

For confirmation of obtaining the vector pNL4-3Luc $\Delta$ Int, 10 bacterial colonies were chosen to perform PCR and digest the amplicons with BsTE-II. As a result, after electrophoresis of the colonies' amplicons, all were positive, amplifying the approximate size of $2837 \mathrm{bp}$. These amplicons were then digested with BsTE-II and the reaction was shown to be positive, confirming the subcloning of the recombinant vector of integrases 
with the reporter gene for luciferase pNL4-3Luc $\Delta$ Int. Two colonies were randomly chosen to perform plasmid preparation according to material and methods and for the following recombination experiments.

\section{Validation assay for recombination of the vector pNL4-3Luc $\Delta$ Int with integrases of different subtypes for the production of infectious viruses}

In order to observe the virus production by correct recombination with integrases and evaluate its production through the expression of the luciferase enzyme, an assay was elaborated through the transfection of the vector pNL4-3Luc $\Delta$ Int with integrase amplicons of subtypes B and C, as described in material and methods. We performed a homologous recombination assay in vitro, where the integrases of subtypes B and C were used (GIBSON DG, et al, 2009).

In separate reactions, the pNL4-3Luc $\Delta$ Int vector previously linearized with BsTE-II was recombined with the respective amplicons. After the reaction, the recombined vector was transformed into competent bacteria. In order to assess correct recombination, colony PCR was performed for the integrase gene region. All the PCR reactions amplified the fragment of approximately $1.2 \mathrm{~kb}$ for the gene and, thus, the correct obtaining of the recombinant integrases was observed. Then, a sequencing reaction was performed for the amplicons of the integrases, in order to confirm the subtypes. The sequences were deposited in the "HIVseq Program: Sequence Analysis", as described in material and methods. The subtypes of recombined integrases were confirmed and the percentages obtained by the database similarity algorithm, as shown in Table 1.

Table 1 - Confirmation of the specific subtype of recombinant integrases after depositing the sequencing in the HIVseq Program: Sequence Analysis database.

\begin{tabular}{cc}
\hline Recombinant integrase & \% of similarity (HIVseq Program) \\
\hline Integrase B & IN B 97.10 \\
Integrase C1 & IN C 97.50 \\
Integrase C2 & IN C 97.30 \\
Integrase C3 & IN C 97.30 \\
\hline
\end{tabular}

Source: Vivarini BCD e Vivarini AC, 2021.

After this recombination assay, the vector pNL4-3Luc-(Int B and C1) was used in the transfection assay. In this transfection, the recombinant integrase vector is circularly transfected, as it contains the integrase gene targeted by the study cloned in the $\Delta$ Int region of the vector. As a result, it was possible to observe high luminescence signals for the vectors previously recombined in vitro, in both subtypes, producing light signals comparable to the positive transfection control pNL4-3Luc (Figure 2a).

In order to observe the infectivity of the recombinant integrase viruses corresponding to the transfection assay, the supernatants collected from the cells were used to infect susceptible cells of MT-4 lymphocyte lineage. It was observed that the viruses produced by the transfection assay promoted high rates of luminescence corresponding to successful infection. In addition, it can be seen that the signals produced by the recombinant integrase virus of subtype $C$ were as high as the positive control and different from the signals for the integrase virus of subtype B (Figure 2b). 
Figure 2 - Luminescence detection of the cell transfection and infection assay.

A

\section{Transfection assay - HEK 293-T cells}

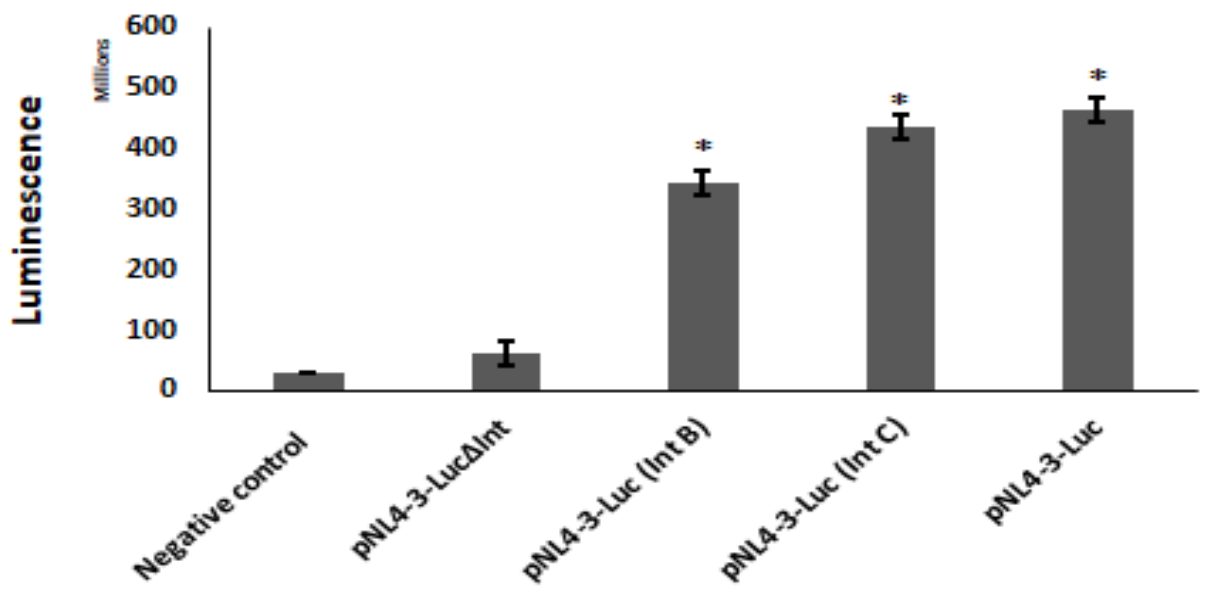

B

\section{Infection assay - HIV-1 Luciferase}

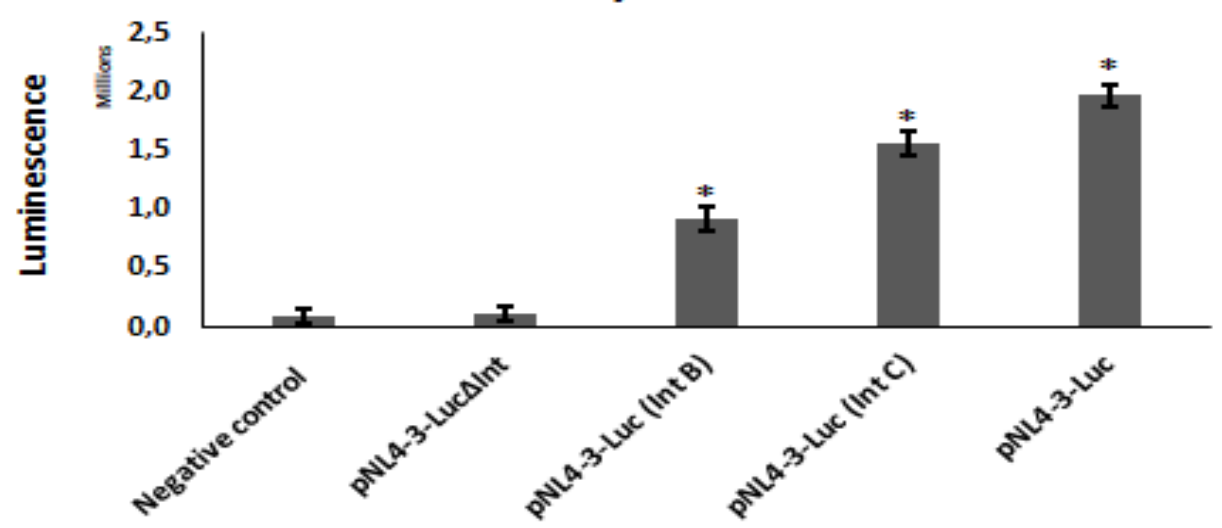

Note: A) HEK 293-T cells were used for transfection. Negative transfection controls are non-transfected cells; as a positive control, the original vector pNL4-3Luc was transfected. pNL4-3Luc (Int B or C) corresponds to transfection of the complete vector with recombinant integrase by homologous recombination assay in vitro. $\mathrm{B}$ ) Infection test of recombinant integrase viruses with luciferase reporter gene from the transfection assay. Detection of the light signal for infectious viruses. As a negative infection control, uninfected MT-4 cells were used; $\Delta$ Int, refers to infection with the transfection supernatant of the linear pNL4-3Luc $\Delta$ Int vector; Luc refers to the infection of HIV-1 Luc viruses generated through the transfection of the original vector pNL4-3Luc; pNL4-3Luc (Int B or C) is infection with the recombinant integrase viruses produced in the transfection assay. $\left({ }^{*}\right)$ indicates a significant difference between the groups by the ANOVA statistical test from the standard deviation between three replicates of each point, with $p<0.05$. Representative result of three independent experiments.

Source: Vivarini BCD e Vivarini AC, 2021.

\section{DISCUSSION}

After years of the first antiretroviral therapy-resistant variant, the detection and characterization of antiretroviral-resistant variants has become essential for the clinical care of HIV-infected patients (MBUNKAH HA, et al, 2020). A wide range of genotypic (based on sequencing) and phenotypic (based on cell culture) assays have been developed to identify and quantify therapy-resistant HIV-1 (CHANG S, et al, 2015). 
One of the challenges for treatment, as well as producing vaccines and curing HIV-1 infection, is the genetic diversity of the virus. Antiretroviral treatment is important for preventing the transmission of the virus, as well as increasing the life expectancy and quality of the infected individual by delaying his progression to AIDS. However, the genetic diversity of the virus directly impacts the highly active antiretroviral treatment (HAART) (CORADO ALG, et al, 2017; VERDE RMC, et al, 2020). The class of Integrase Inhibitor antiretroviral drugs came as the main rescue therapy for individual's resistant to HAARTs. Thus, studies that seek to elucidate the impact on the different integrase subtypes are necessary. There are few studies that evaluate the treatment of INIs on the different subtypes of this enzyme (WAINBERG et al., 2012; DOYLE T, et al, 2015).

But although phenotypic tests are important for the analysis of drug-resistant variants, genotypic tests are still the first choice, especially the most modern ones, such as New Generation Sequencing platforms. They provide a great deal of knowledge about the extent of mutant variants present in a range of pathogens. This is due to the depth of coverage obtained for a given gene or genomic region, as well as the ability to analyze a large number of samples simultaneously. In chronic infections such as HIV, the study of variants is important and determines the outcome of antiretroviral treatment (SILVER N, et al, 2018).

This study consisted of the construction of a recombination vector for integrases of different subtypes, which has the luciferase reporter gene as a tool for phenotypic study of integrases, enabling its use to assess susceptibility to INIs. It is worth mentioning that for the phenotypic evaluation, the use of the recombination plasmid vector is essential. The use of Luciferase as a reporter gene for the resolution of HIV1 phenotypic assays proves to be efficient and widespread in the studies of this virus (MACHADO LA, et al, 2019; ORTA-RESENDIZ A, et al, 2020).

In order to demonstrate the possibility of using the vector constructed for recombination (pNL4-3Luc $\Delta$ Int) with different integrase in relation to the viral subtype, transfection assays were carried out with the specific recombined vector Integrase previously recombined. To this end, the use of homologous in vitro recombination technique has become the strategy of choice. Obtaining recombinants is possible and the intact vector is directly expressed and produces recombinant integrase viruses that can be collected in the transfection supernatant. The luminescence detection was shown to be sensitive to the proposed test, since a possible difference in light signal between the subtypes was obtained.

Therefore, the construction vector allows its use for the production of recombinant integrase viruses for the phenotypic evaluation between different subtypes and possibly against INIs in untreated patients, serving as a guide to specific antiretrovirals, as well as in reissued patients, helping the therapy become more efficient. The test presented in this work also can provide the monitoring of the emergence of resistant variants. Even with its efficiency, additional studies, mainly of the longitudinal type, are necessary for a better understanding of the clinical relevance of minority viral variants.

\section{CONCLUSION}

In conclusion, we were able to build a pNL4-3Luc $\Delta$ Int recombination vector in which could be inserted integrases of different HIV-1 subtypes, allowing for the subsequent phenotypic analysis of the gene mutation variations. The homologous recombination assay was efficient, resulting in recombinant viruses that could be identified indirectly through the Luciferase reporter gene assay by emitting luminescence both in transfected HEK 293-T cells and in MT-4 lymphocytes infected with the viral particles. The present work contributes to the development of phenotypic tests that aim to previously analyze the profile of resistance to INIs in patients with prediction of antiretroviral therapy, favoring a better therapeutic choice. Although there is a need for complex molecular assays, the proposal of the phenotypic test could help temporally and in individual efficiency with the use of antiretrovirals.

\section{ACKNOWLEDGMENTS AND FINANCING}

We thank the Department of Genetics of the Institute of Biology/UFRJ for encouraging research, as well as the College of Sciences, Department of Cell and Molecular Biology in which the cloning were performed. 


\section{REFERENCES}

1. ALBARILLO F, O'KEEFE P. Opportunistic Neurologic Infections in Patients with Acquired Immunodeficiency Syndrome (AIDS). Curr Neurol Neurosci Rep, 2016; 16(1): 10.

2. BLANCO JL, MARTINEZ-PICADO J. HIV integrase inhibitors in ART-experienced patients. Curr Opin HIV AIDS, 2012; 7(5): 415-21.

3. BRACQ L, et al. Mechanisms for Cell-to-Cell Transmission of HIV-1. Front Immunol, 2018; 9: 260.

4. CDC - HIV and AIDS-United States. Morbidity and mortality weekly report, 2001; 50(21): 430-434.

5. CONNOR NR, et al. Vpr is required for efficient replication of Human Immunodeficiency virus type-1 in mononuclear phagocytes. Virology, 1995; 206: 935- 944.

6. CUNNINGHAM AL, et al. Manipulation of dendritic cell function by viruses. Current Opinion in Microbiology, 2010; 13(4): 524-529.

7. GALISTEU KJ, et al. Opportunistic infections among individuals with HIV-1/AIDS in the highly active antiretroviral therapy era at a Quaternary Level Care Teaching Hospital. Rev. Soc. Bras. Med. Trop, 2015; 48(2): 149-156.

8. GERMAN ADVISORY COMMITTEE BLOOD (Arbeitskreis Blut), Subgroup 'Assessment of Pathogens Transmissible by Blood'. Human Immunodeficiency Virus (HIV). Transfus Med Hemother, 2016; 43(3): 203-22.

9. GIBSON DG, et al. Synthesis of DNA fragments in yeast by one-step assembly of overlapping oligonucleotides. Nucleic Acids Res, 2009; 37: 6984-6990.

10. HARDY I, et al. Evolution of a novel pathway leading to dolutegravir resistance in a patient harbouring $\mathrm{N} 155 \mathrm{H}$ and multiclass drug resistance. J Antimicrob Chemother, 2015; 70(2): 405-11.

11. HEGER E, et al. Development of a phenotypic susceptibility assay for HIV-1 integrase inhibitors. J Virol Methods, 2016; 238: 29-37.

12. HEMELAAR J, et al. Global trends in molecular epidemiology of HIV-1 during 2000- 2007. AIDS, 2011; 25(5): 679689.

13. KOLAKOWSKA A, et al. Update on Adverse Effects of HIV Integrase Inhibitors. Curr Treat Options Infect Dis, 2019; 11(4): 372-387.

14. LU DY, et al. HAART in HIV/AIDS Treatments: Future Trends. Infect Disord Drug Targets, 2018; 18(1): 15-22.

15. MINISTRY OF HEALTH. Recomendações de terapia antirretroviral para adultos vivendo com HIV/aids no Brasil, 2019.

16. NEUBERT J, et al. HIV-1 Subtype Diversity and Prevalence of Primary Drug Resistance in a Single-Center Pediatric Cohort in Germany. Intervirology, 2016; 59(5-6): 301-306.

17. OARAC (Office of Aids Research Advisory Council). Guidelines for the use of antiretroviral agents in HIV-infected adults and adolescents. African journal of medical practice, 2012; 5(2): 79-104.

18. PEETERS M, et al. Origin and diversity of human retroviruses. AIDS Rev, 2014; 16(1): 23-34.

19. PLANTIER J, et al. A new human immunodeficiency virus derived from gorillas. Nat Med, 2009; 15(8):871-872.

20. PUJARI SN, et al. Integrase Resistance-Associated Mutations on Raltegravir Failure in Western India: A Preliminary Analysis. J Acquir Immune Defic Syndr, 2018; 77(5): e42-e45.

21. ROBERTSON DL, et al. HIV-1 nomenclature proposal. Science, 2000; 288(5463): 55-56.

22. SALADINI F, et al. Agreement between an in-house replication competent and a reference replication defective recombinant virus assay for measuring phenotypic resistance to HIV-1 protease, reverse transcriptase, and integrase inhibitors. J Clin Lab Anal, 2018; (1): e22206.

23. SANTOS JR, et al. Virological failure to raltegravir in Spain: incidence, prevalence and clinical consequences. J Antimicrob Chemother, 2015; 70(11): 3087-95.

24. SKITTRALL JP, et al. A scale-free analysis of the HIV-1 genome demonstrates multiple conserved regions of structural and functional importance. PLoS Comput Biol, 2019; 15(9): e1007345.

25. UNAIDS. Global report: UNAIDS report on the global AIDS epidemic. Joint United Nations Programme on HIV/Aids (UNAIDS), 2018.

26. WAINBERG MA, et al. The Impact of HIV Genetic Polymorphisms and Subtype Differences on the Occurrence of Resistance to Antiretroviral Drugs. Mol Biol Int, 2012; 2021: 256982.

27. VERDE RMCL, et al. Mutations of antiretroviral resistance and genetic diversity of HIV-1 in pregnant women attended at a reference maternity hospital in the State of Piauí, Brazil. Research, Society and Development, 2020; 9(90): e160996683.

28. CORADO ALG, et al. HIV-1 genetic diversity and antiretroviral drug resistance among individuals from Roraima state, northern Brazil. PLoS One, 2017; 12(3): e0173894.

29. DOYLE T, et al. Integrase inhibitor (INI) genotypic resistance in treatment-naive and raltegravir-experienced patients infected with diverse HIV-1 clades. J Antimicrob Chemother, 2015; 70(11): 3080-3086.

30. MACHADO LA, et al. Raltegravir-Induced Adaptations of the HIV-1 Integrase: Analysis of Structure, Variability, and Mutation Co-occurrence. Front. Microbiol, 2019; 10: 1981.

31. ORTA-RESENDIZ A, et al. HIV-1 acquired drug resistance to integrase inhibitors in a cohort of antiretroviral therapy multi-experienced Mexican patients failing to raltegravir: a cross-sectional study. AIDS Res Ther, 2020; 17:6.

32. MBUNKAH HA, et al. Low-Abundance Drug-Resistant HIV-1 Variants in Antiretroviral Drug-Naive Individuals: A Systematic Review of Detection Methods, Prevalence, and Clinical Impact. The Journal of Infectious Diseases, 2020; $221(10):$ 1584-1597.

33. CHANG S, et al. Comparison of susceptibility of HIV-1 variants to antiretroviral drugs by genotypic and recombinant virus phenotypic analyses. International Journal of Infectious Diseases, 2015; 37: 86-92.

34. SILVER N, et al. Characterization of minority HIV-1 drug resistant variants in the United Kingdom following the verification of a deep sequencing-based HIV-1 genotyping and tropism assay. AIDS Res Ther, 2018; 15:18. 